\title{
FERGE SÁNDOR
}

\section{Közös jószág}

Murphy törvénye szerint ami el tud romlani, az el is romlik. Ennek egyik folyománya az, hogy a bonyolult rendszerek nem müködnek. (Persze Zymurgy ellentétele értelmében az egyszerü rendszerek sem müködnek.) Az információs társadalom termékeinek és szolgáltatásainak (jószágainak) előállítási és alkalmazási folyamataiban sokszor azt tapasztaljuk, hogy „valami nem jól működik”. Ez nem csak a gépekre és a szoftverekre, hanem az információs rendszerekre és a fejlesztési programokra is igaz. Az írás arra keresi a választ, hogy ezeknek a rossz tapasztalatoknak mi az oka? Murphynek van igaza, és az információs társadalom fejlesztésére is teljesül Ginsberg teorémája, („1. Nem nyerhetsz; 2. Nem érhetsz el döntetlent; 3. Még a játékból sem szállhatsz ki.)”? Vagy ez esetben pusztán egy másik „törvény” érvényesül, amely szerint csak azok rendszerek müködnek megfelelően, amelyeknek a működési modellje jól illeszkedik a működtetendő jószág tulajdonságainak? A cikk remélhetőleg meggyőző választ ad a kérdésre, és most kivételesen nem Rudnicki Nobel-díjas alapelve igazolódik, amely szerint: „Csak aki tökéletesen ért valamit, az tud mások számára érthetetlenül beszélni róla.”

\section{Szerzői információ:}

Ferge Sándor

Okleveles építômérnök, gazdasági szakmérnök.

Jelenleg az IHM-ben az ITK'TB Stratégiai Tervezési Albizottság vezetôjeként egyik irányítója a Magyar Információs Társadalom Stratégiát kidolgozó csoportoknak. Az Ybl Fớiskolán a termelésés üzemszervezés elméleti és gyakorlati kérdéseit oktatta. Elektronikus kommunikációval, hálózatos rendszerekkel kapcsolatos fejlesztésekben dolgozott a SZTAKI-ban. Az IIF keretében az IIF X. 25-ös csomagkapcsolt adathálózat központ egyik fejlesztôje volt.

Legutóbb megjelent publikációi: A távmunka informatikai vonatkozásai (Távmunka tanácsadóKJK 2003.); Az információs társadalom és az eÉpítốipar (Magyar Építôipar 2003.)

Így hivatkozzon erre a cikkre:

Ferge Sándor. „Közös jószág ”.

Információs Társadalom V, 1. szám (2005): 82-93.

$=$ https://dx.doi.org/10.22503/inftars.V.2005.1.6

A folyóiratban közölt müvek 
Ferge $\mathrm{S}$ án dor

\section{Közös jószág}

Van egy szép magyar szó: a ,jószág”. Nem (csak) azért szép, mert hangzása a „jóság"-ra rímel, hanem mert átvitt értelemben is használható. A háziállatok mellett mindenféle jó dolgot, terményt, terméket, kincset, sốt árut, szolgáltatást is jelenthet. Az angoloknak is van egy szép szavuk az effélére: goods. Érdekes (vagy talán természetes?), hogy ennek a jelentése - áru, árucikk - majdnem megegyezik a mi „jószág” szavunkéval, miközben ez is nyilvánvalóan a „jó” (good) tớból származik.

Mondják, hogy a nyelv és a gondolkodás szorosan összefügg. Az angolban többféle goods van: private goods („magán jószág”), club goods (, klub jószág”), common goods („közös jószág”) és public goods (, közösségi jószág”).

Hogy is van ez magyarul? Léteznek ezek a szavak a mi szótárunkban, ${ }^{1}$ megvannak ezek a fogalmak a mi gondolkodásunkban is?

Az információs társadalomról sokan gondolkodnak, beszélnek, írnak. Sokan próbálják megfogalmazni annak a változásnak a lényegét, amit a huszadik század végén, a huszonegyedik század elején tapasztalunk. Van, aki a lényeget az információban látja, és azt olyan ,árunak” tartja, amelyet minél több felé osztunk, annál több lesz belóle. Az információt - tekintettel erre a jó tulajdonságára - szép magyar szóval megjelölve „közös jószágnak” is nevezhetnénk. Az igazán jó pedig az volna, ha nemcsak így neveznénk, hanem annak is tekintenénk, aminek lennie kell: „közjószágnak”, ${ }^{2}$ még pontosabban „közösségi jószágnak”.

A huszadik század végi, huszonegyedik század eleji változásokkal sok kutató foglalkozik. A változás lényegét keresve megállapítják, hogy az „ipari társadalom” gazdaságának alapja, a „piac”, és az arra épülő „piacgazdaság” egyre több esetben „nem múködik". Mi a piacgazdaság múködésének lényege? Egyik oldalról minden bizonnyal az árutermelés. A piac egyik oldalán múködő „szereplók” árukat állítanak elớ. Ốk adják a kinálatot. Olyan árukat, amelyekre a piac másik oldalán elhelyezkedő fogyasztók igényt tartanak. Lehetóleg sokan. Ők jelentik a keresletet. Az áruk természete általában az, hogy egy adott árut egy adott idôpontban csak egy valaki birtokolhat. Ez a piac múködésének lényeges eleme. Jó esetben többen is kínálnak egy-egy árut, és többen tartanak rá igényt. Az, hogy végül kié lesz az áru, és milyen áron cserél gazdát, a piac múködése során dól el. Milyen érdekesen változik is a nyelv... Manapság igencsak furcsán hangzana, ha a köznyelvben , jószágtermelésról”, , jószágcserérôl” beszélnék. Nem volt ez mindig így, pedig a piacot a régi idókben is piacnak hívták, ráadásul akkor még viszonylag jól is múködött. Mi okozza ma a piac múködésének zavarait?

${ }^{1}$ A Pallas-lexikonban a jószág: tágabb értelemben mindenféle, akár ingó, akár ingatlan vagyon. Szorosabb értelemben mezei földbirtok. Lábas-jószág alatt pedig a gazdasági haszonállatok értetnek. Jószág nemzetgazdasági értelemben: Javak.

${ }^{2}$ A „közös jószágok” és a „közösségi jószágok” együttese. 
A kérdéssel foglalkozó kutatók ennek egyik - talán legfóbb - okaként a keresleti vagy a kínálati oldal torzulásait említik. Ilyen torzulás a kínálati oldalon a monopóliumok kialakulása, ami megakadályozza a valódi verseny kialakulását. Véleményem szerint ilyen ok a keresleti oldal manipulálása is, nevezetesen a mesterséges igénykeltés, illetve igénykorlátozás (jogi vagy erkölcsi tiltás). Illetóleg a „piac kudarcáról” beszélnek abban az esetben is, ha nem sikerül valamely jószágot piacivá tenni, hatékony újratermelését, elosztását piaci eszközökkel megoldani.

Ma már szinte minden szakértố egyetért abban, hogy a piac múködésének zavaraiért és kudarcaiért - legalábbis részben - a kínálati és a keresleti oldal nagyon eltérố „informáltsága" is felelốs. Az információkból nyerhető ismeretek szintjében a piac két oldalán mutatkozó különbségek annál nagyobb problémát okoznak, minél inkább olyan termékról (jószágról) -úgynevezett tudásipari termékról, röviden tudástermékekról van szó, amelynek az előállítása sok hasznosított ismeretre, tudásra épül. Nem véletlen tehát, ha az „információs társadalom” fejlődésével és terjedésével párhuzamosan egyre többször tapasztaljuk a piac olyan múködési zavarait, amelyeket az információs különbségek okoznak.

Más kutatók „a piac kudarca” mellett „az állam kudarcáról” is beszélnek. ${ }^{3}$ Az állam feladata többek között a piac „,normális múködésének” biztosítása, a „beavatkozás” azokon a területeken, amelyeken a piac „nem múködik”, illetve nem múködhet normálisan, valamint a „megoldások” biztosítása az élet olyan szféráiban, amelyek nem tartoznak a piac által kezelhetố területek közé. Az információs társadalom kialakulása mindhárom feladat kapcsán jelentôs kihívást jelent az állam számára.

A piac mindkét oldalának torzulása megfigyelhetô. A kínálati oldalon a monopóliumok kialakulása ugyan nem tartozik az információs társadalom specifikus vonásai közé, de a keresleti oldalon megfigyelhetók olyan jelenségek, amelyeket a mesterségesen gerjesztett igények már leginkább az „új gazdaság” sajátos melléktermékeiként hívnak életre. A fogyasztókra minden érzékszervüket egyszerre bombázó, kontrollálatlan információáradat zúdul - itt most elsôsorban azokra a multimédia jellegú ,jószágokra” (vagy inkább „rosszaságokra” ${ }^{4}$ ) gondolok, amelyek a fogyasztói társadalom viselkedési, életviteli mintáit közvetítik -, amelynek még a legedzettebb információs állampolgár (cyber citizen) is csak nehezen tud ellenállni, az állam számára pedig ez a kihívás kezelhetetlennek látszik.

Az állam különféle „,beavatkozásai” a piac múködésébe akkor is kockázatosak, ha teljes mértékben indokoltak és adekvátak. Ennek különféle formái közül elsôsorban a pénzügyiek veszélyesek. Ezek közül is kiemelten a pénzügyi támogatás különféle formáira gondolok akkor, amikor elvileg elhibázottnak mondom azokat a beavatkozásokat, amelyek az eltérő informáltságból fakadó piaci kudarcot kívánják orvosolni. Az a jól ismert mondás, miszerint , az éhes eszkimónak nem halat kell adni, hanem hálót”, tömören ugyanezt fejezi ki. A kellő (megfeleló) információ hiánya az embereket kiszolgáltatottá teszi ,a piaci eróknek”. Ezt a problémát pénzügyi támogatással pró-

${ }^{3}$ Joseph E. Stiglitz (2003): Ethics, Market and Government Failure, and Globalization. Nicholas Barr (1987): The Economics of the Welfare State. Weidenfeld and Nicholson.

${ }^{4}$ Érdekes, hogy a szükségtelen dolgokra az angol használja is a „bads”, „rosszaság” szót ...mi ugyanezt általában vulgárisabban fejezzük ki... 
bálni orvosolni olyan, mint abban a bizonyos régi viccben a kolhoz csirkéinek 10-10 kopejkát adni: hadd egyenek, amit akarnak, ha éhesek. Az információs társadalom „jószágainak” piaca egyre inkább olyan portékákat kínál, amelyek igénylik a sokféle információt, az alapos ismeretet, a tudást. Nem csoda tehát, ha egyre fokozottabban jelentkeznek a piac kudarctünetei és az állam tehetetlenségének jelei, a beavatkozási kísérletek kudarcai.

A legnagyobb kihívással azonban a harmadik területen áll szemben azállam. A társadalom életének ugyanis vannak olyan problémái, amelyekról senki sem gondolja, hogy a piaci mechanizmusok spontán múködése fogja megoldani óket. Ilyen például a természeti kincsek (a jó levegố, az „élhetô környezet”) védelme vagy a biztonság megteremtése. Nem véletlen, hogy egyre többen gondolkodnak az ipari társadalom vagy a kapitalizmus válságáról akkor, amikor azt tapasztalják, hogy egyre több olyan dolog válik „piacivá”, amely azelốtt „,közös jószágnak” számított, és senki sem gondolta, hogy az ezekhez való hozzáférést bárki számára piaci alapon kellene biztosítani. Ha a „közös jószág” fogalma nem is, az e fogalomkörbe tartozó dolgok köre jelentôsen megváltozott. A közös jószágok száma csökkent: - egyre több vált közülük áruvá: ez jelentette a piacgazdaság kialakulását. Minốségi összetételük változása - egyre több szolgáltatás közös jószággá válása - magával hozta a „szociális piacgazdaság” megjelenését. Mindezeknek a közös jószágoknak a biztosítása mindig valamely közösség, legtöbb esetben az állam feladatát jelentette. Akkor, amikor olyan korban élünk, amelyben nem szentségtörés bármit potenciális árunak tekinteni és a róla való gondoskodást a piacra bízni (kufárkodni vele), azaz a „közös jószágok” körét egyre tovább szúkíteni, nem csoda, ha a piacgazdasággal kapcsolatban egyre nó a kiábrándultság. Különösen akkor válik elgondolkodtatóvá a helyzet, amikor olyan közös jószágok válnak áruvá (olyan dolgokat kívánnak egyesek azzá minôsíteni), amelyek definíciószeríen nem felelnek meg ennek a fogalomnak. Mi is ez a definíció?

A ,jószágokat” a közgazdaságtan négy csoportra osztja. Kétfelé aszerint, hogy kirekesætố jellegúek-e vagy sem (kizárható-e valaki azoknak a köréból, akik hozzájuk férhetnek), s megint két csoportra annak alapján, hogy versengó természetük van-e vagy sem (vagyis egy-egy példányuk egyszerre csak egy emberé lehet-e, tehát versengeni kell-e érte).

A jószágok közgazdasági besorolása (és néhány példa):

\begin{tabular}{||l|l|l|l||}
\hline \multirow{2}{*}{ A jószág } & \multicolumn{3}{|c||}{ Jellege szerint kirekesztó? } \\
\cline { 2 - 4 } & \multicolumn{1}{|c|}{ IGEN } & \multicolumn{1}{|c|}{ NEM } \\
\hline $\begin{array}{l}\text { Természete } \\
\text { szerint } \\
\text { versengó? }\end{array}$ & IGEN & $\begin{array}{l}\text { magán jószág: } \\
\text { könyvek, játékok, élelmiszeripari } \\
\text { termékek, kórház (gyógyítás, ápolás) }\end{array}$ & $\begin{array}{l}\text { közös jószág: } \\
\text { a tengerben levó halak, úthálózat, } \\
\text { ásványkincsek }\end{array}$ \\
\cline { 2 - 4 } & NEM & $\begin{array}{l}\text { klub jószág: } \\
\text { mozi (film), színdarab, iskola (oktatás) }\end{array}$ & $\begin{array}{l}\text { közössési jószág: } \\
\text { nemzetbiztonság, közbiztonság, } \\
\text { jó levegố }\end{array}$ \\
\hline \hline
\end{tabular}

Megjegyzések: A jószágok versengố természete akként értelmezhetố, hogy miáltal az egyik ember a jószágot igénybe veszi (fogyasztja, használja), azáltal a másiknak kevesebb vagy semmi nem juthat belóle, mert a jószág (el)fogy vagy hozzáférhetetlenné válik. Egy könyvet ketten olvasni, ugyanazt az ételt többen enni, egy kórházi ágyban többen feküdni nagyon nehéz, az úton nem fér el mindenki, a kincset kibányászni, a halat kifogni csak egyszer lehet. 
A jószágok kirekesztô jellege fizikailag és/vagy jogilag értelmezhetô. Vannak jószágok, amelyeknél ez a két értelmezés azonos, mások esetében ellentmondó lehet. Az emberek által előállított kézzelfogható termékek (könyv, moziépület, mozifilm-kópia) esetében fizikailag egyértelmú az IGEN, a természet „,korlátlan” kincsei esetében fizikailag egyértelmú a NEM. Egyes fizikailag nem létező „jószágok”, mint például a biztonsági és az egészségügyi szolgáltatás vagy az igazságszolgáltatás (helyesebben: jogszolgáltatás) esetében a válasz jogilag NEM, míg más „,szellemi jószágok" (pl. a szellemi tulajdonok) és egyes jogosítványok (pl. bizonyos szolgáltatások nyújtására szóló engedélyek) esetében ilyen szempontból IGEN a válasz. Furesa helyzet áll eló abban az esetben, ha a kétféle értelmezés szerinti válaszok ellentmondanak egymásnak (pl. halászati jog, bányászati jog, közoktatás, közegészségügy).

A ,jószág” és a ,jóság” hasonlósága nem véletlen. Sok más nyelv is - nemcsak az emlegetett angol - a „jót” kifejezô szóból származtatja a „jószágnak” megfelelő szavakat. Bár nem vagyok etimológus, úgy gondolom, ez bizonyára azért van így, mert ezek a szavak olyan ,jó” dolgokat jelentenek, amelyekre az embereknek igényük, szükségük van. Igen fontos kérdés, hogy ezeknek az igényeknek a kielégítése hogyan történik. Miután ,jó" dolgokról van szó, amelyekre sok embernek van igénye, viszont nagyon kevés olyan (definíciószerúen: nem kirekesztő és nem versengố) „közösségi jószág” van, amely bárhol, bármikor, bárkinek a rendelkezésére áll, fontos kérdéssé válik, hogy hogyan, milyen módon történik az igények kielégítése.

A jószágok üjra-elöállitásának, illetve az emberek számára hoz:áférhetơvé tételének megoldásával kapcsolatban több kérdés merül fel. Kinek a feladata a jószágokról való gondoskodás? Kinek a feladata és kinek a felelóssége, hogy meglegyenek ezek a jószágok, és kinek az, hogy hozzájuk lehessen jutni? A válasz nyilvánvalóan bonyolult, de minden bizonnyal úgy kezdődik, hogy „ez attól függ, milyen jószágról van szó...”. (A milyen kérdőszóval itt a fenti - magán, klub, közös, közösségi-kategóriákba sorolt tulajdonságokat kívánom jelezni.) A jószágok elérhetôségének „,biztosítása” nyilvánvalóan sok és sokféle tevékenységet jelent. Tekintsük ezeknek a tevékenységeknek egy-egy konkrét jószág esetében is összetett együttesét „rendszernek”. Bármilyen bonyolult rendszerról legyen is szó, a vele kapcsolatos kérdések manapság elóbb-utóbb leegyszerúsödnek erre az alapkérdésre: „Ki finansæirozza?”. Habár minden bizonnyal ez a legfontosabb kérdés, emellett még egy másikat is célszerú megvizsgálni. Ez a kérdés arra irányul, hogy az adott rendszernek mi a „modellje”. Jómagam - informatikus lévén - azt vallom, hogy minden múködő rendszernek van modellje. Sốt, ennek az ellenkezôjét is hiszem: azok a rendszerek, amelyeknek nincs modelljük vagy ellentmondásos modelljük van, nem múködnek (más szavakkal: a pénz önmagában nem old meg egyetlen problémát sem). A kérdés tehát úgy is feltehetố, hogy mi a müködés modellje, vagy akár úgy is, hogy kinek a felelóssége az, hogy legyen müködő modell és az müködjön is, azaz ki müködtesse a rendszert. Miután a válasz úgy kezdődik, hogy „ez attól függ...”, bővítsük ki az elốzố táblázatot: 


\begin{tabular}{|c|c|c|c|}
\hline $\begin{array}{c}\text { A jószágok } \\
\text { csoportosítása }\end{array}$ & Kirekesztố & Nem kirekesztố & $\begin{array}{l}\text { Az ellátó rendszer } \\
\text { modellje }\end{array}$ \\
\hline Versengô & Magán & Közös & $\begin{array}{l}\text { verseny a kínálati oldalon, } \\
\text { verseny a keresleti oldalon, } \\
\text { szabad alku }\end{array}$ \\
\hline Nem versengô & Klub & Közösségi & $\begin{array}{l}\text { kínálati oldalon lehetséges } \\
\text { verseny, } \\
\text { keresleti oldalon nincs ver- } \\
\text { seny, } \\
\text { alku helyett elosztási sza- } \\
\text { bály, vagy döntési módszer }\end{array}$ \\
\hline $\begin{array}{l}\text { A rendszer } \\
\text { finanszírozása }\end{array}$ & $\begin{array}{l}\text { A megfelelő modell jel- } \\
\text { lemzóje, hogy a jószág új- } \\
\text { ra-elóállítását és használa- } \\
\text { tát azok finanszírozzák, } \\
\text { akik a jószághoz hozzáfér- } \\
\text { nek. Amennyiben a kire- } \\
\text { kesztés jogi vagy fizikai ok } \\
\text { miatt történik meg, a nem } \\
\text { kirekesztettek fizetik, } \\
\text { azért mert ók nincsenek } \\
\text { kirekesztve. Amennyiben } \\
\text { a jószág a finanszírozási kö- } \\
\text { telezettség miatt válik ki- } \\
\text { rekesztővé, akik fizetik, } \\
\text { azért férhetek hozzá, mert } \\
\text { ók finanszírozzák. Az utób- } \\
\text { bi esetben a modell meg- } \\
\text { felelóségéhez a kirekesztés } \\
\text { módjának elfogadottsága is } \\
\text { szükséges. }\end{array}$ & $\begin{array}{l}\text { A ,,nem kirekesztố” tulaj- } \\
\text { donság nem jelenti azt, } \\
\text { hogy a gyakorlatban min- } \\
\text { den ember igénybe is fogja } \\
\text { venni a jószágot. Egy meg- } \\
\text { feleló finanszírozási mo- } \\
\text { dellben az a „mindenki”-t } \\
\text { reprezentáló közösség fi- } \\
\text { nanszírozza a jószágot, } \\
\text { amelynek esetében a kö- } \\
\text { zösség minden tagja közel } \\
\text { egyenló eséllyel válik a jó- } \\
\text { szág haszonélvezójévé, il- } \\
\text { letóleg egyformán igényli } \\
\text { azt, miközben a ,potya- } \\
\text { utasok” száma tolerálható- } \\
\text { an alacsony. }\end{array}$ & \\
\hline
\end{tabular}

A válasz a „kirekesztô” és „versengó” tulajdonságú, azaz magán jószágok esetében viszonylag egyszerúnek tûnik. Ebben az esetben a klasszikus vagy versenypiaci modell jól múködik, mivel éppen erre van „kitalálva”. A modell összhangban van a jószágok tulajdonságaival. Akik a jószágokhoz hozzájutnak, azok fizetik meg a jószágok árát, mégpedig azoknak, akik a jószágokat előállítják és eljuttatják hozzájuk, vagyis elosztják, az ár pedig a piaci verseny és a piaci alku során alakul ki. Mi a helyzet azonban a többi jószággal?

A klub jószágok esetében olyan modell kellene, amelyben - tekintettel a jószág kirekesztố természetére - az egyéni finanszírozás (azok által, akik nincsenek kirekesztve) párosul a kommunális elosztással (vagyis azok, akik egy-egy ilyen jószágot finanszíroztak, további verseny nélkül hozzájutnak). Ez a modell - nagyjából - úgy múködik, hogy a jószágot ténylegesen igénybe vevố személyek vagy csoportok felosztják egymás között a jószág előállításának (és igénybevételének) költségeit. Ebben a modellben a felosztandó költségek elvileg függetlenek az igénylók számától, mivel a jószág nem versengố tulajdonságú. A klasszikus piaci modell nem múködóképes, mivel a keresleti oldalon az egymással versengố fogyasztók nem jelennek meg, illetve nem nyilvánítják ki valódi preferenciájukat (a jószág szempontjából pedig mindegy, hogy hányan veszik igénybe, illetve egyáltalán igénybe veszik-e), nincs alkuhelyzet. A jószág árát csak az újra-előállítás költségei határozzák meg. A jószágot ténylegesen igénybe vevő szereplôk száma - és így az általuk „fejenként” fizetendố rész - csak utólag (a jószág elóállítása és a tényleges használata után) állapítható meg. A kereslet pedig a legtöbb esetben ettól a „fajlagos” költségtôl (ár) függ. Mivel a tényleges igény eloore nem állapítható meg, 
„piaci ár” nem tud kialakulni, s így a piaci múködés célja, a tisztességes haszon sem értelmezhető. (Tipikus példát jelentenek erre a kulturális és sport-rendezvények. A jegyek árát elốre meg kell mondani ahhoz, hogy azokat az esemény elótt el lehessen adni. Utólag derül csak ki, hogy ezen az áron kevés lesz-e a nézô, vagy éppen ellenkezóleg, és a feketepiacon tömegjelenetek kíséretében történik meg az újabb kirekesztés. Azt a kockázatot viszont senki sem vállalná, hogy az elôadás után kiszámított díjat fizesse a jegyért.)

A közös jószágok elméletileg megfelelő modelljében - tekintettel arra, hogy ezek a jószágok nem kirekesztố jellegúek - mindenki közös finanszírozással, piaci feltételek mellett jut a ,jószághoz”. Nyilvánvaló, hogy a gyakorlatban a mindenki pontosabban értelmezendő. Annak ellenére, hogy a jószág elméletileg nem kirekesztố, ritkán tekinthetố mindenki (a világ összes embere) potenciális igénylőnek vagy igényjogosultnak. Így a mindenki legtöbbször csak egy kisebb közösség tagjait (például egy ország állampolgárait) jelenti. A közös finanszírozás legtöbbször a közösség tagjainak valamilyen közös „kalapba” (például a költségvetés, valamint különféle alapok, alapítványok bevételi számláira) történő befizetéseivel oldható meg. Ezt igyekszik modellezni például a közbeszerzés. ${ }^{5}$ A piaci ár itt ki tud alakulni, a problémát annak elszámolása jelenti. Miután az ilyen jószág versengố természetú, és az igénybevétel általában nem a közös kasszába történố befizetés arányában alakul, a befizetôk egy része igazságtalannak fogja érezni a költségviselést. (Kicsiben bizonyára mindenki átélte ezt, például egy baráti társaság közös üdülése alkalmából. Abban mindenki egyetért, hogy a közös fogyasztások finanszírozására kell „közös kassza”, ami még mindig jobb, mint megpróbálni minden kiadást személyre lebontva, egyénileg rendezni. Mégis nehéz olyan befizetési elvben megállapodni, amelyet mindenki igazságosnak érez, és utólag is maradéktalanul elégedett vele.)

Itt megjelenik az úgynevezett „potyautas” (free rider) probléma is, ami akkor áll elő, ha az adott közösséghez nem tartozó személyek is részesednek a jószágból. Ez amellett, hogy a költségviselést utólag meg kellene változtatni - azzal is gondot okozhat, hogy versengô jószágokról lévén szó, esetleg nem jut elegendô az eredeti közösség tagjainak.

Ha úgy tetszik, a közösségi jószágok múködési és múködtetési modelljével van a legnagyobb baj, hiszen a fent említett problémák mind fennállnak: a kereslet és a kínálat nem állítható szembe, nincs alkuhelyzet, az igazságos teherviselés csak nehezen oldható meg, és itt nehezen értelmezhetố a versenyhelyzet, amit legfeljebb mesterségesen lehet megteremteni. Mégis, talán ebben az esetben oldható meg legkönnyebben a probléma - legalábbis elméletileg. A mindenki köre ugyanis ekkor - tekintettel az ilyen jószágok nem kirekesztô jellegére - tetszólegesen nagy lehet, és mivel a jószágok nem is versengô jellegúek, az sem lényeges, hogy előre pontosan tudjuk, kik és milyen számban jelentik a közösséget. Ha sikerül a jószágot élettartama alatt elegendô számú igénybevevóhöz eljuttatni, akkor mindenki jól jár.

\footnotetext{
${ }^{5} \mathrm{Ez}$ az eljárási rend formálisan igyekszik követni a valódi piaci mechanizmust, az ajánlatok bekérésekor verseny-elemekkel (többfordulós pályázatok, licitálás), az értékeléskor pedig többszempontú tudományos döntés-elókészítési módszerek (költségelemzés, kockázatkezelés stb.) alkalmazásával. Ugyanakkor annak, aki az adott jószágnak sem effektív haszonélvezóje, sem a közös kassza igazi tulajdonosa, nehéz ebben az eljárásban valódi tulajdonosi szemlélettel „mindenki” érdekeit érvényesíteni.
} 
Nehéz jó modellt találni a különféle közös vagy közösségi igények kielégítése terén még az elméletileg meghatározottaknak pontosan megfelelố tulajdonságokkal rendelkezó „tiszta jószágok” esetében is, a valóságos jószágok esetében pedig, amelyeknek a tulajdonságai különféle okok miatt vegyesek lehetnek és ezért nem az egyes típusoknak megfelelő módon „múködnek”, még nehezebb.

Furcsa a helyzet például az egészségüggyel. Tulajdonságait tekintve tipikus „magán jószág”. Hiszen kirekesztố, hacsak - természetesen a közös kassza terhére - nem építünk annyi kórházat és nem foglalkoztatunk annyi orvost, hogy gyakorlatilag korlátlan kapacitás álljon rendelkezésre. Ugyanakkor rivalizáló is, hiszen egy orvos csak egy beteget tud gyógyítani egyszerre. A szolidaritás mégis a közös jószágok közé soroltatja velünk, hiszen egészségesként sem tudnánk jól érezni magunkat, ha sokan lennének betegek körülöttünk, amiatt mert nem képesek megfizetni a gyógyítás költségeit. Mégis - mintegy elismerve, hogy valójában „magán jószágról” van szó minduntalan felmerül a javaslat, hogy a közös finanszírozás az igénybevétel arányában történjen (vagy a befizetésnek megfelelố szintú legyen az ellátás, ami gyakorlatilag ugyanaz).

Manapság a megfelelő modell keresése nem más, mint a piaci modell valamilyen változatának alkalmazása (adaptálása) a különféle jószágtípusokra. Ezek a kísérletek nézetem szerint azon a feltevésen alapulnak, hogy a piaci modell múködóképes, alapfeltételei érvényesek a közös jószágokra is, értelmezhetók a keresleti és kínálati görbék, elérhető a Patero-hatékony tényezô felhasználás, a döntések (a profit maximalizálás szempontjából) racionálisan születnek és a saját érdekeikból cselekvő egyének egyben a közösség érdekeit is szolgálják.

Régi meggyốzôdésem, hogy csak azok a rendszerek múködnek megfelelöen, amelyeknek a múködési modellje jól illesskedik a múködtetendô jószág tulajdonságaihoz.

Ezen „törvényból” adódó követelményeket a példaként említett egészségügyi gyakorlatban az ellentmondásós helyzet, máshol pedig esetleg más okok miatt nehéz érvényesíteni. Logikusnak túnik tehát alapjában véve a versenypiaci modellból kiindulni, de ehhez - tekintettel a jószág alapvető tulajdonságaira - szorosan kapcsolódnia kell a szolidaritást modellező támogatási rendszernek is. Még így is megmarad persze a piac kínálati és keresleti oldala között mutatkozó jelentôs információs különbségek problémája, ${ }^{6}$ ami miatt nincs valódi alkuhelyzet és a versenypiaci modell múködése kudarcra van ítélve.

Ennek kapcsán érdemes megállapítani, hogy a múködési modell visszahat a jószág „viselkedésére”. Az egyéni, illetve a felhasználás mértékével arányos finanszírozás például kirekesztốvé teszi a jószágokat. Még a természetes jellegénél fogva legkevésbé kirekesztô jószág is kirekesztốként viselkedik, ha személyenként kell érte fizetni.

Gondoljunk példaként a parkolási díjra. Az egyéni dífizetést ebben az esetben az indokolja, hogy versengổ jószágról van szó, és az ilyen tulajdonságú jószágokat - a fenti törvényszerúség miatt - célszerú piaci modell alapján múködtetni. Ezáltal viszont a State. 2001.

${ }^{6}$ Nicholas Barr: The Welfare State as Piggy Bank. Information, Risk, Uncertainty and the Role of the 
jószág kirckesztôvé válik, hiszen csak annak van joga parkolni, aki megfizeti annak díját. Nem csoda tehát, ha igen magas a szabálysértések aránya, ami a rendszer múködési zavarát jelzi. (Adekvát modellben nem egységes lenne a parkolási dijj, hiszen nem a kirekesztést kívánjuk modellezni. A parkolási díjnak az elfoglalt területtel, a kereslet-kínálattal arányosnak kellene lennie, ami a versengó tulajdonság modellezését jelentené, továbbá a „számla” utólagos kiegyenlítésére az üzleti élet szabályai vonatkoznának, nem pedig a szabálysértési eljárásé.)

Fentebb, a jószágok tulajdonságait elemezve az volt látható, hogy a piaci modell feltételeinek egyike-másika, vagy akár egyidejúleg több is, nem áll fenn, ami egyben magyarázatot is ad a nem megfelelô múködésre utaló tapasztalatokra. Magától értetôdően felvetốdik a kérdés: van-e más múködóképes modellünk (nonprofit vagy civil modell), amely a közjószágok esetében alkalmazható volna?

Mi a helyzet például az információs társadalom sajátos ,jószágaival”, elsősorban az információval? Az információ semmiképpen sem tekinthetô versengó természetû jószágnak. Ritka az olyan információ, amit ne lehetne elvileg korlátlan számú igénylóhöz eljuttatni. Egyetlen információ - ameddig egyáltalán információ marad - tetszóleges számú embert képes „kiszolgálni”. Furcsa tehát az információ „áráról” beszélni, legföljebb az előállítás (és a felhasználóhoz való eljuttatás) költségeirôl beszélhetnénk. A kérdés csak az, hogy ezeket a költségeket milyen közösségnek kellene állnia, vagyis ez a jószág kirekesztố jellegúi-e. Ezt különféle jogi (és erkölcsi) korlátok szabályozzák, amelyek az információt néha - mindenki mást kirekesztve - egyetlen ember vagy egy kisebb csoport tulajdonává tehetik (üzleti titkok, bizalmas adatok stb.). Ezektól az esetektôl eltekintve azonban az információ alapvetốen nem kirekesঞtố jellegú. Lényegi tulajdonságai alapján tehát az információ közjószágnak tekintendő. (S mivel nem versengó természetú, ezért közösségi jószág.) A magyar törvényi szabályozás egyértelmúen ezt mondja ki. A törvény azonban nem írja elő (nem is tudná előírni), hogy mely információkra mekkora közösségnek van igénye, vagyis mekkora közösségnek kellene megfizetnie az információ-jószággal kapcsolatos költségeket. Ennél is nagyobb problémát jelent, hogy a szabályozás azt sem mondja meg, mely költségelemek értendók bele ezekbe a költségekbe, vagyis nem igazít el arra vonatkozóan, hogy az információ milyen megjelenési formában tekintendő közösségi jószágnak. Ez a gyakorlatban azért okoz problémát, mert az információ - ha úgy tetszik - nem „tiszta jószág”. Mindig valamilyen formában testesül meg, és ez lehetôséget ad arra, hogy sajátos érdekek átminôsítsék, és ettól függóen azután vagy magán- vagy közös jószágnak számítson. Amikor az információ nyomtatott formában jelenik meg, a könyv-jószág mintájára kíván viselkedni, olyannyira, hogy szinte minden megjelentetett információ a legszívesebben igényt tartana a szellemi tulajdon státusára (és a szerzói jog által biztosított védelemre). Az információs társadalom egyik nagyszerú „,közmúve” - az internet - megoldást kínál erre a problémára (is). Szemben a könyvekkel, amelyek valóban versengó természetú jószágok, a világhálón megjelenó honlapok nem azok. Megvan az a jó tulajdonságuk, hogy elvben mindenki számára elérhetók, elérhetôségüket a példányszám nem korlátozza, tehát a haszonélvezók közössége tetszólegesen nagy lehet. Az interneten közzétett információk elóállításának költségei is lényegesen alacsonyabbak a nyomtatásban terjesztett információkénál. A világhálón való megjelenés nemcsak a könyv-jószág útján történő infor- 
mációközlésnél, hanem a rádión és a televízión keresztül megvalósuló tájékoztatásnál is lényegesen olcsóbb, hiszen itt minden információ folyamatosan ,adásban van”. Úgy tûnik, pusztán szabályozás kérdése, hogy az információk milyen formában közölve minôsülhetnek valóban közösségi jószágnak, jogi eszközökkel megakadályozva a kirekesztést. Az alacsony fajlagos költségek ehhez viszonylag tág teret biztosítanak.

Ennek persze az egyik legfontosabb feltétele az, hogy az említett „közmú” valóban mindenkinek rendelkezésére álljon. A nem is olyan hosszú távon várható elónyök miatt érdemes elgondolkodni azon, hogy e probléma megoldására milyen modell lenne a legmegfelelóbb. Szakmai körökben egy ideje nagy vita folyik arról, hogy az információs társadalomnak ez az alapvetố fontosságú közmúve miféle jószágnak tekintendô. Vannak, akik az internetet egyértelmúen közösségi jószágnak tartják, és a hozzáférést közösségi beruházás útján valósítanák meg. Mások magán jószágnak tekintik és alapvetốen a versenypiaci modell alkalmazása mellett kardoskodnak. Véleményem szerint mindkét nézet helytálló lehet, csakhogy itt voltaképpen két különböző, bár egymással nagyon szorosan összefüggó jószágról van szó. Az egyik az a hálózat, amely valóságos vagy virtuális vezetékekból áll, és mint ilyen leginkább a többi hálózatos infrastruktúrára (pl. víz-, csatorna-, elektromos- vagy akár úthálózat stb.) hasonlít. Ezek a jószágok nem kirekesztô jellegúek, hiszen - ha léteznek - tetszóleges létszámú közösség tagjait képesek kiszolgálni. Ugyanakkor versengố természetúek, mert kapacitásuk nem végtelen, és újabb fogyasztók bekapcsolása csökkenti a többiek esélyeit a megfelelố ellátásra. Az ilyen tulajdonságok tehát az alap-infrastruktúrának ezt a részét közös jószágként azonosítják. A másik jószág az internetkapcsolat biztosítása (valójában a TCP/IP protokoll szolgáltatása). Ez a jószág viszont kirekesætố jellegú, mivel az IP-cím nem természettôl fogva létezô dolog, hanem elố kell állítani. ${ }^{7}$ (Tovább fokozza ezt a problémát, hogy a ma használatos $I P$-címek kifogyóban vannak). Még inkább ilyen az IP alapú kapcsolat, amelyet mindenki számára külön-külön, újra és újra fel kell építeni. Ugyanakkor természetesen mindét jószág versengoó természetû is, hiszen a korlátos erôforrások és kapacitások miatt minden egyes új kapcsolat kiépítése rontja a többiek kiszolgálásának az esélyeit (egy IP-címen, csak egy berendezés múködhet, minden kapcsolat újabb sávszélességet igényel), s emiatt ez a szolgáltatás magán jószágnak tekintendô. Kétféle - eltérố tulajdonságokkal bíró - jószágot egyetlen öszvérként modellezni elméletileg is igen nehéz, s a gyakorlatban megfelelően múködő modellt találni szinte lehetetlen. Ha a magán jószágokra alkalmazható versenypiaci modellt választjuk, a kiépülố hálózat - a jószág alaptermészetével ellentétes módon - kirekesztốen viselkedik. (A múködési modell visszahat a jószágra: a magántulajdonnak már csak ilyen a természete). Ha viszont közös jószágként modellezzük és újra-előállításának költségeit nem fizetjük meg, akkor a jószág elóbb-utóbb „elfogy”, vagy a minôsége jelentôsen romlik. Csak az látszik megfelelő megoldásnak, ha az infrastruktúra e két elemét kétféle múködési modell alapján - a hálózatot közös jószágként, az IP-szolgáltatást pedig magán jószágként kezeljük. Úgy túnik, hogy ennek a kivitelezésére napjainkban jó esélyünk lenne. Csupán

${ }^{7}$ Az IP-címek - az egyébként nem kirekesztő számok felhasználásával - az ember által létrehozott termékként funkcionálnak. Azáltal válnak virtuálisan létező dologgá, hogy különféle nyilvántartásokba bejegyzik ốket, tulajdonost és egyéb paramétereket rendelve hozzájuk. Függetlenül attól, hogy kell-e azért díjat fizetni, vagy sem, aki nincs nyilvántartásba véve, az ki van rekesztve. 
szabályozási kérdésnek látszik, hogy a jószágokat megkülönböztessük, és megfelelóen azonosítsuk. Ez tulajdonképpen a jelenlegi szabályozás „fordítottját” jelentené, vagyis nem arról van szó, hogy a hálózat tulajdonosa köteles azt más szolgáltatók számára átengedni (bár ez is fontos mindaddig, amíg a hálózatok magán jószágok maradnak), hanem arról, hogy a szolgáltatás valaki másnak a hálózatán milyen feltételekkel biztosítható. Ily módon a közmú-társulásokhoz hasonló konstrukció jöhetne létre. Egy-egy település vagy kistérség, esetleg egy-egy régió úgy dönthetne, hogy a közösség közös kasszájából kiépíti saját hálózatát, majd a közös jószág segítségével igénybe veszi valamely szolgáltató $I P$-szolgáltatását. A kivitelezéshez az adhat jó esélyeket számunkra, hogy a közös beruházás pénzügyi fedezetét a sokat emlegetett európai fejlesztési alapok biztosíthatják a közösségek számára.

Az információs társadalom egy másik - különösen érdekes - jószága a szoftver. Bizonyára izgalmas vitát lehetne nyitni arról, hogy mi a szoftver, mi a jelentôsége, milyen szempontból különösen érdekes, de most csak a jószág természetét vizsgáljuk meg. Azt könnyú belátni, hogy a szoftver nem versengố jellegú. Ez meglepố ugyan, de így van, hiszen azáltal, hogy valaki használ egy szoftvert, senki másnak az esélyét nem csökkenti annak használatára, tehát elvileg nem kell versengeni érte.

A másik kérdés az, hogy a szoftver kirekesztó jellegü-e vagy sem, és ez már sokkal nehezebben megválaszolható. Amennyiben a szoftvert információnak tekintjük, azt a választ kell adnunk, hogy nem kirekesætó! 'Természetesen - az információhoz hasonlóan meg lehetne vizsgálni, hogy milyen szoftverról van szó, mi a tartalma, „miról szól”. E vizsgálat alapján lehetne egyes szoftver-típusokat kirekesztốnek minôsíteni, meghatározva azokat a sajátosságokat, amelyek alapján egy szoftver - megváltoztatva a jószág eredeti tulajdonság szerinti viselkedését - ilyenné tehetô.

Ha azonban a szoftverre, mint szellemi termékre tekintünk, azt lehet mondani, hogy kirekesztó jellegú, hiszen egyes emberek vagy csoportok szellemi terméke, és ha az övék, akkor természetesen nem lehet másoké. A találmányok, múalkotások esetében ez meglehetốsen egyértelmú, és senki sem vitatja ezeknek a jószágoknak a kirekesztô jellegét, amit a szellemi tulajdonhoz füződő szerzói joggal kifejezésre is juttat, lehetôvé téve a szellemi tulajdon szabadalmazhatóságát is. Kérdés, hogy a szoftvert találmánynak vagy múalkotásnak lehet-e tekinteni? Magam is egyetértek azzal, hogy ha ilyen jellegú szoftver termék készül, akkor arra ugyanazok a szabályok vonatkozzanak, mint az egyéb találmányokra és múalkotásokra, bár véleményem szerint csak nagyon kevés ilyen szoftver akad. De találmánynak tekinthető-e az, ha valaki pusztán egy probléma létezô megoldását írja le, oly módon, hogy az mások számára is kezelhetôvé váljék és az adott problémára megoldást jelentsen. A hangsúly itt a „leíráson”, vagyis bizonyos gondolatoknak, összefüggéseknek vagy szabályoknak a megfogalmazásán, illetve a megfelelő nyelvre való lefordításán van. A szoftver ugyanis a legritkább esetben találmány. Aki szoftvert készít, az nem talál fel semmi újat, pusztán egy probléma létezô megoldását vagy a megoldás módszerét írja le, ebben az esetben úgy, hogy az számítógépek által kezelhetố legyen, más szóval a probléma megoldását vagy a megoldás módszerét emberi nyelvról gépi nyelvre fordítja le.

Miért van mégis annyi probléma a szoftverek körül? Az egyik legfóbb ok a múködési modellek visszahatása a jószágok viselkedésére. A szoftverekre szükség van. Mivel a szoftverek iránti igényt kezdettól fogva a versenypiaci múködés-modellnek megfelelően 
elégítjük ki, a szoftver magán jószággá vált (hiszen a versenypiaci modellnek - tulajdonságaik alapján - az ilyen jószágok felelnek meg). Hogyan érte ezt el a piac? Úgy, hogy a szoftvert kirekesঞtố és versengó jellegúvé tette (pedig alaptermészete szerint nem volna az), vagyis a múködési modell visszahatott a jószág viselkedésére. Hogyan vált a szoftver-jószág versengó jellegúvé? Elsốsorban a licencdíjak révén. A licenc a versengó jószágok piaci kezelésének eszköze. Ha egy jószágfajtából - még ha nem kirekesztó jellegú is, mint például a rádiófrekvenciák - véges számú egyed létezik, akkor nagyon is indokolt lehet, hogy használatuk bizonyos jogosítványokhoz legyen kötve, például licencdíjak formájában. Annak ellenére, hogy a szoftver alapvetốen nem versengố természetú, a licencdíj által „sikerült” azzá tenni. Ezt elősegítette az is, hogy a szoftverek - a könyvekhez vagy a mozifilmek kópiáihoz hasonlóan - kezdetben mindig valamilyen kézzelfogható formában jelentek meg. Ez a forma eleinte lehetett papírszalag, lyukkártya, mágnesszalag, mágneslemez vagy papír-alapú dokumentáció. Késóbb a gyártók a „dobozos" szoftverek forgalmazásával igyekeztek azt a látszatot kelteni, hogy ez a jószág is olyan, mint a szórakoztatóipari vagy irodatechnikai termékek. A fogyasztókban azt az érzést alakították ki, hogy valamilyen konkrét játékot vagy eszközt vásárolnak, s így sikerült elfogadtatniuk velük a licencdíjat. (Nem kétséges, hogy az illegálisnak minôsített másolatok magas száma itt is a nem megfelelố múködési modellre utal.)

Annak érdekében, hogy a szoftver teljes mértékben megfeleljen a magán jószág kritériumainak, a szoftvert kirekesztốvé is kellett tenni. Ennek eszközei a szeræói jog és a sæabadalom. Az elsố békát a felhasználók már lenyelték, a másodikat most igyekeznek a torkukon lenyomni. Az elsố a szoftver szellemi alkotás-jellegét fejezi ki, a másodikat pedig a szoftver találmány-jellege alapján kellene elfogadni. Márpedig - mint fentebb igyekeztem megmutatni - ez korántsem tekinthetố a szoftver jellegzetes vonásának, és nem tekinthetố sem nyilvánvalónak, sem egyértelmúnek. Inkább az látszik valószínúnek, hogy nagyon is kevés olyan szoftver van, ami indokoltan részesül a szellemi alkotásnak járó jogvédelemben.

Ahogyan az egészségügy kapcsán meg kellett jegyezni, hogy a keresleti és a kínálati oldal információs természetü, tudásbeli kiilönbségei a piaci múködés zavarát eredményezik, ez ugyanúgy elmondható a szoftverpiacról és az információs társadalom piacairól általában is. A szoftverek készítói (egyes esetektól eltekintve) nem gazemberek, nem becsapni akarják a felhasználókat, hanem csupán saját érdekeiket érvényesítik. A szoftverkészítés speciális tudást igényel, és egy bonyolult szoftver elkészítése meglehetôsen nagy munka. Mint ilyen, nagyon sokba kerül. A fejlesztók ezeket a magas költségeket igyekeznek így vagy úgy megfizettetni a felhasználókkal. Ez természetes is. A probléma egyfelól az, hogy azokat a fejlesztéseket is megfizettetik, amelyek nem hasznosulnak: számos új szoftverró́l hosszabb-rövidebb idő után kiderül, hogy nem „múködik”, vagyis nem oldja meg azt a problémát, amelynek a megoldása érdekében készült, tehát hasznavehetetlen jószág (angolul az ilyesmit néha - a goods ellentéteként - a bads kategóriájába sorolják). Másfelól pedig, hogy a jószág tulajdonságainak nem megfelelô múködési modell miatt ezek a költségek vagy nem térülnek meg, vagy pedig -indokolatlanul - sokszorosan is megtérülnek.

Mi a megoldás? A válasz egyszerúnek látszik: a tudáskiülönbség csökkentése és a megfeleloo múködési modell alkalmaæása. A megoldás a valóságban is egyszerú lehet, bár nem kecsegtet túl gyors sikerrel. A felhasználók információs, tudásbeli elmaradása és ebból 
adódó kiszolgáltatottsága folyamatosan csökken. Elóbb-utóbb valódi alkuhelyzet alakulhat ki, és ott, ahol valóban piaci modellnek kell múködnie, elegendố tudás lesz ahhoz, hogy a piaci kudarcok elkerülhetók legyenek. Ennél is nagyobb optimizmusra ad okot az, hogy a szoftver-jószág tulajdonságait figyelembe véve a versenypiaci múködés modellezése nem is indokolt. Szerencsére a szoftverek esetében létezik azt kiváltani képes múködési modell. Ennek alapján kezdôdött meg az olyan nyílt forráskódú és szabad szoftvereknek ${ }^{8}$ a fejlesztése és elterjesztése, mint amilyen például az egyre többek által ismert Linux, Apache, Open Office vagy Mozilla. A modell kidolgozóinak és múködtetốinek attitû́djét és szándékát jól kifejezi az az egyetlen játékos múszó, a copyleft, ${ }^{9}$ amely nem pusztán a szó „kifordításával”, a copyright tagadásaként, a szoftverek nem kirekesztő és nem versengố tulajdonságait elismerve rögzíti a nyílt forráskódú és szabad szoftverek terjesztésének feltételeit.

Egyes országok már kezdik kihasználni ezt az új lehetôséget, és most úgy tûnik, hogy nálunk is jó alkalom nyílik erre. Az információs szabadságról készülố törvény -a szoftver-jószágok (vagy bizonyos típusú szoftver-jószágok) közösségi jószág, esetleg klub jósæág természetét elismerve - teljes értékú létjogosultságot biztosíthatna a szoftverellátás nem versenypiaci múködési modelljének. A szoftverek iránt igényt támasztó közösség a legritkább esetben azonos egy-egy ország vagy régió lakosságával. Ebben az esetben sokkal inkább a foglalkozás vagy az érdeklódési kör a csoportképzó tényezó. A különbözố csoportok szükségleteit kielégítô szoftverek előállítását, terjesztését, karbantartását és fejlesztését biztosító rendszerek kialakításában és múködtetésében nagyon nagy szerep hárulhat tehát a civil társadalomra. A problémák megoldásának realitását - azon kívül, hogy bízunk a jószágok tulajdonságaihoz jól illeszkedô múködési modellek sikerét garantáló törvényben - az ország új fejlesztési tervei (Európa Terv, NFT II.) biztosíthatják. Az európai fejlesztési alapok segítséget adhatnak a nem versenypiaci modellek alkalmazásához szükséges pénzügyi források megteremtéséhez, és ezúttal talán szerencsésnek érezhetjük majd magunkat, ugyanis a közösségi modelleknek az a kockázata, hogy a közösségi jószág haszonélvezói lehetnek olyanok is, akik nem vesznek részt a finanszírozásában (,„potyautas” probléma, „SI faktor”) minimálisra csökken: a magyar nyelvú szoftvereket csak mi fogjuk használni. 